\title{
Karşılaştırmalı Kamu Yönetimiyle İlişkisi Bakımından Ania Loomba'nın Yöntemi
}

Karşılaştırmalı Kamu Yönetimiyle İlişkisi Bakımından Ania Loomba'nın Yöntemi

$\ddot{O} z$

Loomba, kolonyalizm ve postkolonyalizmi incelerken Avrupa-merkezci düşünceye eleştiri getirmekte; konu, zaman ve mekân bakımından postmodern çokkatlılık ve parçal1lıkla uyumlu bir yaklaşım geliștirmektedir. Ancak Loomba postmodern incelemelerin ayrıştırdığı parçalar arasındaki ilişkilere odaklanmayı da önermektedir. Bu doğrultuda Loomba'nın karşılaştırmalı yöntemi alanyazındaki genel durumdan bazı noktalarda farklılaşmaktadır. Çokkatlı ve parçalı olan bu yaklaşım parçalar arasında bağlantı kurabildiği ölçüde karşılaştırmalı kamu yönetimi için bir katkı sunma potansiyeli taşımaktadır. Bu çalışmada Loomba'nın kolonyalizm ve postkolonyalizmi ele alırken başvurduğu karşılaştırmalı yöntemin temel özellikleri ış1ğında karşılaştırmalı kamu yönetimi alanında yapılan çalışmalara sunabileceği katkı incelenecektir. Çalışmanın amacı Loomba'nın karşılaştırmalı analiz içinde bulunduğu konumu saptamak ve karşılaştırmalı kamu yönetimi için önerebileceği yolu anlamaya çalışmaktır.

Anahtar Sözcükler: Karşılaştırmalı Kamu Yönetimi, Ania Loomba, Kolonyalizm, Postkolonyalizm.
Ania Loomba's Method Concerning Comparative Public Administration

\section{Abstract}

While examining colonialism and postcolonialism, Loomba criticizes the Eurocentric perspective and develops an approach consistent with the multiplicity and fragmentation of postmodernism in terms of subject, time, and space. Nevertheless, Loomba also suggests focusing on relations between the fragments of postmodern analysis. Accordingly, her comparative method differentiates from the rest of the literature at some points. Loomba's approach would potentially contribute to comparative public administration to the extent that it makes a connection between fragments. This paper examines Loomba's potential contribution to the studies in comparative public administration in light of the main characteristics of her comparative method used when dealing with colonialism and postcolonialism. The purpose of this paper is to reveal Loomba's position in comparative analysis and to attempt an understanding of potential ways which Loomba might suggest for comparative public administration.

Keywords: Comparative Public Administration, Ania Loomba, Colonialism, Postcolonialism.

\section{Giriş}

Ania Loomba, ${ }^{2}$ Batı'da üretilmiş yazın ve bilgiye dönük eleştirel bir yaklaşıma sahiptir. Batı kaynaklı bilginin evrensellik ve tarafsızlık temalarını sorgulamakta; bunu yaparken de postmodernizmin kavrayış ve analiz unsurlarından yola çıkmaktadır. Bu bağlamda yazar, çokkatlı ve parçalı bir söylem analizini kullanır; edebi metinleri ve siyasal-toplumsal önemi olan söylemleri inceler. Bu noktada, postmodern yaklaşıma yönelik bir eleştiri de getirmekte, sadece parçalılığa dayalı bir analizin yararlı olmayacağını, bunu yaparken parçalar arasında bağlantı kurulması gerektiğini savunmaktadır (Loomba, 2000, s. 33 ve 268-269). Diğer yandan, karşılaştırmalı yöntemin de, evrensellik iddiasındaki bir Avrupa-merkezci tutum olduğunu öne sürer. Ancak, bu karş1 çıkışa rağmen karşılaştırmanın uygun şekilde kullanılabilecek bir araç olduğunu da düşünmektedir. Loomba'ya (2009, s. 502-503) göre modernite öncesi dönemi yok sayan sınıflandırmalardan arındırıldığında karşılaştırma yararlı biçimde kullanılabilir, bu sayede yöntemin eksikleri de giderilebilir.

\footnotetext{
${ }^{1}$ Gökhan Aşkar is a Research Assistant at Karabuk University, Department of Political Science and Public Administration, Karabuk, TURKEY. gokhanaskar@karabuk.edu.tr, ORCID: 0000-0003-2603-0817

${ }^{2}$ Ania Loomba, lisans ve yüksek lisans eğitimini Delhi Üniversitesi'nde, doktorasını da İngiltere'de Sussex Üniversitesi'nde tamamlamıștır. Halen Pennsylvania Üniversitesi'nde erken dönem edebiyat, ırk ve kolonyalizm tarihi, postkolonyal çalışmalar, feminist kuram ve çağdaş Hindistan edebiyatı ve kültürü üzerine çalışmalar yapmaktadır. Loomba'nın Güney Asya Feminizmleri, Postkolonyal Çalışmalar ve Kolonyalizm-Postkolonyalizm gibi eserleri bulunmaktadır (University of Pennsylvania, 2021).
} 
Bu çalışmada ilk olarak Loomba'nın kolonyalizm ve postkolonyalizm incelemeleri üzerine bir değerlendirme yapılacak ve yazarın uluslararası bağlamda ürettiği bilgi incelenecektir. İkinci olarak yazarın içinde bulunduğu kavramsal konumlanışın karşılaştırmalı yöntem içindeki yeri tartışılacaktır. Yazar, doğrudan doğruya karşılaştırmalı kamu yönetimi üzerine bir çalışma yapmamış olsa da, mevcut çalışmalarından yola çıkarak ürettiği karşılaştırmalı kamu yönetimine yönelik bilgi ve sonuçları, yazarın konumuyla birlikte değerlendirilecektir.

\section{Kolonyalizm-Postkolonyalizm Çalışmaları ve Ania Loomba}

Grosfoguel'in (2011) de ifade ettiği üzere Batı felsefesine yönelik epistemolojik eleştirilerle, modern kapitalizm ve dünya sistemi temelli kolonyalizm çalışmalarının evrensellik ve tarafsızlık iddiaları sorgulanmaktadır. Kolonyalizm geçmişine sahip ülkelerden kimi yazarlar, iktidar yapılarının düşünce dünyamızı etkilemesi üzerine tezleriyle öne çıkmaktadır. Buna göre sınıf, ırk, coğrafya ve cinsiyet gibi temeller üzerine yükselen modern dünya bağlarından kaçış bulunmamaktadır. Postkolonyal eleştiri ise kapitalizmi bir kültürel sistem olarak ele alır; buna göre kültür küresel kapitalizm içinde ekonomik ve politik ilişkileri belirleyen temel unsurdur. Burada postkolonyal kuramcılar politik ekonominin öneminin farkında olsalar da olgunun kültürel çerçevede nereye oturacağ1 konusunda belirsiz bir modele sahiptirler (Grosfoguel, 2011).

Kolonyalizm, kavramsal anlamda, bir ülkenin diğeri üzerinde işgal ve kontrol yoluyla kurduğu egemenlik biçimi olarak görülmektedir (Hiddlestone, 2009, s. 2). Kolonyalizm işgal sürecini betimlerken, emperyalizm bundan daha geniş bir otorite ve egemenliği içermektedir. Postkolonyalizm de temel olarak kolonyal dönemin sonrasını ifade eder (Hiddlestone, 2009, s. 2). $\mathrm{Bu}$ açıdan 20. yüzyılın ortasından itibaren çöküşe geçen kolonyal hegemonyaların bıraktığı miras, postkolonyal çalışmaların odak noktasını oluşturmaktadır.

Öte yandan, postkolonyalizm ve kültür temelli eserler kimi Marksistlerin eleştirilerine de konu olmuştur. Örneğin Dirlik (1998), odak noktası olarak kültürel unsurları alan postkolonyal çalışmaları maddi koşulları gizlemekle ve küresel kapitalizmin etkisini göz ardı etmekle suçlar (Hiddlestone, 2009, s. 183). Dirlik (1998, s. 4-5), postkolonyalizmi postmodernizmin bir türevi olarak alır ve kültür temelli eleştirel yaklaşımlarla ilişkilendirir. Farklılık, 'öteki’yi var eden, dil ve kimliği belirleyen bir unsur olarak postmodern yaklaşımların temelinde yatan olgudur ve bu yaklaşımlar politik ekonomiyi göz ardı ederek, kültürel ve edebi çalışmaları merkeze koyarak dünyayı açıklamaya girişmiştir. Harvey (1992, s.116-117) postmodernizmin yalnızca farklılığı ve parçalılığı anlamaya çalışmadığını, bunun da ötesinde parçalanma halini normatif bakımdan önerdiğini ifade etmektedir. Öyle ki, akıl temelinde yükselen eylemliliğin, evrensel olduğu iddia edilen önermelerin reddine dayanan postmodern kabul, aynı zamanda yerel ve tikel olanın fetişleştirilmesinin de kapısını aralamaktadır (Harvey, 1992, s. 116-117). Bu noktada bilimsel araştırmalar açısındansa bir konu zenginliğinin ortaya çıktığı inkâr edilemez. Kimlik siyaseti, etnisite-ırk çalışmaları ve egemen paradigmaya karşı gelişen üçüncü dünya feminizmi postkolonyalizm çalışmalarının merkezi alanını oluşturmuştur (Dirlik, 1998, s. 5-6).

Loomba, genel anlamda yukarıda sunulan çerçeveye yakın çalışmalar yapsa da, postkolonyal alanyazınına ilişsin görüşleriyle eleştirel bir konumdadır. Bir röportajında, Loomba, Kolonyalizm-Postkolonyalizm isimli kitabında postkolonyalizm hakkında söylediklerini tekrarlar (Cohen, 2008). Loomba'ya göre, postkolonyalizm terimine dikkatli yaklaşılmalı, postkolonyalizm koloni geçmişi olan tüm ülkeleri tanımlayabilecek ve açıklayabilecek bir kavram olarak düşünülmemelidir. Örneğin, Hindistan, Kenya ve Mısır gibi ülkelerin kendilerine has tarihsel özellikleri bulunmaktadır. Bu ülkeler, postkolonyalizm çalışmalarında genel olarak yapıldığı gibi, salt kolonyal dönem kapsamında incelenemez (Cohen, 2008). Üstelik mevcut dünya düzeni neokolonyal unsurlara sahiptir, postkolonyal çalışmalar bu durumu gizleyen bir kavramsallık taş1maktadır. Loomba'ya göre, aslında, postkolonyal çalışmalar ortaya çıtıkları evrede feminizm, 
postmodernizm ve psikanaliz gibi alanlardan da beslenerek yeni kavram setleri ortaya çıkarabilmiş, kuramsal anlamda iyi eserler üretilen bir alan olabilmiştir. Ancak, yeni kavramların tekdüze kullanımı anlaşılırlığa da zarar vermektedir (Cohen, 2008).

Shankar (1999), Loomba'nın postkolonyalizm üzerine çalışma yapan diğer isimlere nazaran daha çok yol kat ettiğini düşünmektedir. Bu anlamda Loomba, erken dönem modern Avrupa ve modern Hindistan dışında örneğin Güney Afrika'yı da incelemiştir. Loomba çalışmasına, postkolonyal incelemelerdeki terimlere dair kavramsal açıklamalarla başlar. Ardından, postkolonyal çalışmaları kuramsal çerçeveye oturtur ve çalışmaların, postyapısalcı yaklaşımla ilişkisinin altını çizer. O'na göre, Marksizm temelli bakış açısı, kolonyalizmde ekonomik ilişkilerin konumunu gereğinden çok vurgulamıştır. Ancak bu aşırılık vurgusunun yanında, Loomba, Marksizm'in anti-kolonyal mücadeleye de esin kaynağı olduğunu söylemektedir (Shankar, 1999, s. 149-150). Bu türden bir dikotomi, doğal olarak kapsamı geniş tutmayı gerekli kılmakta ve Shankar'a (1999, s. 150) göre bu, Loomba'nın işini zorlaştıran bir etken olmaktadır.

\section{Loomba'nın Karşılaştırmalı Yönteminin Genel Hatları}

Karşılaştırmalı yöntem, 19. yüzyıldan itibaren bilimsel bir konuma yerleşmiş, zaman ve mekân sınırlamaları bu dönemde geliştirilmiştir. Bu bağlamda sınırlı birtakım olguların karşılaştırılması da giderek terk edilmiş ve bütünsel anlamda toplumlara odaklanılmaya başlanmıştır (San, 1993, s. 157). Karşılaştırmalı yöntemin bu yöndeki gelişiminin bir başka getirisi, belirli bir mekândaki modern döneme ait olguların, modern dönem öncesindeki başka mekânlara özgü örneklerle karşılaştırılamayacağı iddiasıdır. Günümüze kadar gelişimi dikkate alındığında, karşılaştırma yönteminin zaman ve mekân boyutlarından soyutlanarak, karşılaştırılabilirlik ölçülmeksizin ve sosyo-kültürel çevrelerden bağımsız olarak ele alınamayacağı düşünülmektedir (San, 1993, s. 159). San (1993, s. 159) aksi durumların keyfi ve bilimsellikten uzak sonuçlar doğuracağını iddia etmektedir.

Loomba'nın karşılaştırmalı yöntem algısı Avrupa kökenli gelişim çizgisinden farklılaşmaktadır. Loomba'ya (2009, s. 501) göre karşılaştırmalı yöntem, küresel anlatılar bulma amacını taşıyan Avrupa-merkezci bir tutuma sahiptir. Bununla birlikte, Avrupa-merkezci tutumun modern dönem öncesi süreçleri ihmal eden kategorilerine karşı çıkarak daha geniş bir zamana yayılan bir karşılaştırmanın yapılabilirliği üzerine düşünmektedir (Loomba, 2009, s. 502-503). Örneğin, rrkçılık üzerine yapılacak bir karşılaştırmada, geniş bir tarihsel pencere açılmalı ve modern dönem öncesi ırkçılık da incelemeye katılmalıdır. Böyle bir analizde din, bilim ve kültür bir arada resmedilebilecek ve kolonyal tarih ilgili mekânların farklı tarihsel süreçleri bağlamında karşılaştırılabilecektir (Loomba, 2009, s. 503). Loomba'ya göre, örneğin Hindistan'da kast sistemi ve irkçılık birlikte değerlendirilmemiş, tarihsel süreçler ve farklı coğrafi alanlar birbirinden ayrı ele alınmıştır. Tam aksine, eğer süreçler ve bölgeler arası düşünülebilirse, kolonyal ırk ideolojilerinin niçin şu andaki biçimini aldığı kavranabilir (Loomba, 2009, s. 516). Anlaşılacağ1 üzere, Loomba, San'ın (1993) sözünü ettiği karşılaştırmalı yöntemin zaman ve mekân boyutlarının dışında yer almakta, zaman ve mekâna karşılaştırmalı yöntemin klasik yaklaşımının tersine daha esnek yaklaşmaktadır. Bu durum yaptığı incelemeye ve ulaşacağı sonuçlara yönelik farklı yansimalar getirecektir.

Bu bağlamda Loomba (2000, s. 283), Chakrabarty'den yaptığ 1 bir alıntıyla yöntem açısından konumunu ortaya koymaktadır. Söz konusu alıntıda, Chakrabarty, akademik tarih söyleminin tüm kolonyal ülke tarihlerinde Avrupa'nın hükümran öznesi olmayı sürdürdügünü savunmaktadır. Üçüncü dünyada üretilen çalışmalar Avrupa tarihine atıfta bulunurken, Avrupa çıkışlı yayınlar üçüncü dünya tarihine gönderme yapma gereksinimi duymaz. Bu durum, Chakrabarty'ye göre, Avrupa üçüncü dünyayı bilmezken, üçüncü dünyadaki çalışmaların Avrupa'yı bilmenin yararlı olduğunu benimsemesinden kaynaklanmaktadır. Yöntem ve amaç açısından, üçüncü 
dünya yazarları Avrupa'yı taşralaştırarak, egemen bakışı tersine çevirmek zorundadır (Loomba, 2000, s. 283-284).

Loomba'ya (2000, s. 285) göre, postkolonyal çalışmalar üçüncü dünyanın küreselliğini anlatan ve birbirinden farklı sosyal, kültürel ve ekonomik olguları içeren 'yerel durumlar'la daha çok bağlantı kurmalıdır. Kolonyal bakışın barındırdığı tahakkümü ve engellemeleri belirlemek, geçmişe yönelik bir analizi benimsemek ve üçüncü dünyalıların kendi tarihlerine ve olanaklarına yoğunlaşmak Loomba'nın yöneldiği yöntemsel konumun sacayaklarıdır (Loomba, 2000, s. 286). Öte yandan, Loomba'nın üçüncü dünya aydınları ve melezlik üzerine söyledikleri de karşılaştırmalı yöntem içindeki temel derdini ortaya koymaktadır. Buna göre, örneğin kolonyalizm sürecinde karşılaşan kültürler arasındaki farklılıklara odaklanmadan hem kolonyalistlerdeki hem de kolonileştirilmiş toplumlardaki -entelektüeller başta olmak üzere- melezleşmeleri açıklayamama sorunuyla yüz yüze kalırız (Loomba, 2000, s. 206). Buradan da anlaşılacağı üzere temel karşılaştırma öğesi kültürler arasındaki farklar olarak öne çıkar. Tarihler ve mekânlar arasında yapılacak bir incelemede kültürlerin kendine özgü özellikleri belirleyici olacaktır.

Loomba (2000, s. 93), araç olarak da edebi metinleri merkezi bir konuma yerleştirmektedir. O’na göre dil ve göstergeler ideolojik çarpışmaların yaşandığı bir alandır ve kolonyal karşılaşma esnasındaki etkileşimlerin çözümlenmesinde önemli bir yere sahiptir. Edebi metinler sadece hâkim söylemi yansıtmamakta, kolonyal kültürlerdeki çatışmaları ve farklılıkları da betimlemektedir. Loomba (2000, s. 126-127), bu anlamda, kolonyal dönem metinlerinden örneklerle kültürel karşılaştırmalara girişir. Örneğin Britanyalılar, güney denizlerinde seyahat ederken yerli halkların yamyam olduklarına dair izler aramışlar ve bu durum farklı topluluklarda farklı sonuçlar vermiştir. Hawaililer, önce adalarına gelen kolonyalistlerin bizzat kendilerinin yamyam oldukları bilgisini üretmeye bașlamıșlar, ancak onlarla mücadele olanağ bulunmamasından zamanla -insan eti yemedikleri halde- kendilerini yamyam olarak tasvir etmeye başlamışlardır. Bununla birlikte insan eti yiyen Maoriler de, söz konusu etkileşim sürecinde yamyamlıklarına dair söylemi abartma yolunu seçmişlerdir. Burada Loomba açısından söz konusu olan, edebi metinler ve seyahatnameler vasıtasıyla tarihsel olguların çözümlenebileceğine dair olan inançtır. Loomba, bu bağlamda, karşılaştırma yöntemini temel olarak edebi söylem üzerinden kurmayı tercih etmektedir.

Kolonyalistlerin yerel nüfuslarla kurduğu ilişki biçimleri de Loomba için önemli bir konuma işaret etmekte, ilişkiler arasındaki farklılıklar değişik sonuçlar üretmeye dönük bir nedensellik oluşturmaktadır. Loomba'ya (2000, s. 135) göre bu tür farklılıkların birbirinden ayrı ırk söylemlerinin ve kimliklerinin üretilmesinde önemli etkisi bulunmaktadır. Örneğin, İngilizler yerli nüfustan insanlarla evlenmeye yanaşmaz ve bu durumu aşağllarken; İspanyol ve Portekiz kolonyalistleri kolonilerde yerleşmişler, göreneklere uyum sağlamışlar ve yerli halktan kişilerle evlenmişlerdir. Loomba bu durumun nedenleri üzerinde belirli bir açılamaya girişmemekle birlikte, sonuçlarıyla daha çok ilgilenmekte ve melezlikle ortaya çıkan karma kültürleri incelemesine dâhil etmektedir. Nedensel olaraksa, başka bir yazardan yaptığı alıntı, Portekizlilerin ve İspanyolların irk duygusundan yoksun olabileceği üzerinedir (Loomba, 2000, s. 135). Göreneklere uyum sağlama, duygu durumları üzerine bir neden arayışı ve kültürel vurgular karşılaştırmanın neden-sonuç ilişkisinde bulanık bir tablo ortaya çıkarmaktadır. Bu tabloda sonuçlar tartışılmakta ve nedenler belirsizleşmektedir.

Loomba'nın kolonyalistler açısından yaptığı ırksal karşılaştırmalar daha kültürel odaklıyken, kolonileştirilmiş toplumlarda ırk olgusu bakımından belirli ölçüde sınıf temelli açıklamalarla buluştuğu da gözlemlenmektedir. Loomba (2000, s. 153) rrk ve sınıf ilişkisi açısından Marksist ve Weberyan geleneklere işaret eder. O’na göre ilkinde irksal ve toplumsal gruplaşmalar ekonomik yapılarca belirlenirken; ikincisinde sosyolojik temalar ön plana çıkar ve ekonomi temelli açıklamaların yetersizliği vurgulanır. Loomba, ırk ve sınıfı kesiştiren açıklamalara daha yakındır. Ona 
göre kolonileştirilmiş ülkelerde özgür emek mevcut olmamış, zor gücüyle ırksal ayrımlar üzerinden bir emek gücü meydana getirilmiştir. Loomba'ya (2000, s. 152) göre sınıf oluşumu rrksal ilişkilerle doğrudan bağlantılıdır ve kapitalizm ırk ayrımlarını ortadan kaldırmamış, aksine bu ayrımlar üzerine inşa edilmiştir.

Kolonilerde devlet ve kurumlar da tam bu noktada işlevsellik kazanmaktadır. Irksal-sınıfsal ayrımlar kapitalizmin inşasında elzem olan ideolojiler için muhafaza işlevi görür. Örneğin Kenya'da devlet, emek sömürüsünde ve mülkiyet ilişkilerinde önemli bir konuma sahip olmuştur (Loomba, 2000, s. 153). Bu noktada Loomba'nın, ülke karşılaştırmalarında daha tutarlı bir yöntemsel konuma oturduğu gözlenir. Bir bakıma, farklılaşmaların kaynağına dair açıklamalar daha açı olgular üzerine bina edilmiş ve söylem alanındaki belirsizlikler ciddi ölçüde giderilmiştir.

Loomba, kolonyalizmin ülkeler üzerine etkilerini karşılaştırırken toplumsal cinsiyet temasına ve kültürel dönüşümlere de önemli bir konum atfeder. Bu anlamda, Loomba'ya (2000, s. 193) göre, kolonyalizm anasoylu (matrilineal) özelliklere sahip topluluklar üzerinde hayati etkiler b1rakmıştır. Söz konusu dönüşüm, topluluklar arasındaki kültürel farklarda yansımasını bulur ve ittifaklar burada gelişir. Örnekse, Hinduizm'in patriyarkal özellikleri Hindistan'daki anasoylu alt toplulukların biçimlendirilmesinde ve dönüştürülmesinde önemli bir yerde durur. Hinduizm'in katı patriyarkal içeriği Hindistan'da homojen bir yapıyı oluşturmayı kolaylaştırmış ve mevcut hiyerarşileri sağlamlaştırmıştır. Bu durumun sonucu olarak, Nair toplulukları gibi anasoylu gruplar dönüştürülmüş, bunlar Batılı ataerkil bir aile modeline evrilmiştir. Bu noktada, cinsiyet konumlanmaları değiştiği gibi mülkiyet ilişkileri de bundan etkilenir ve üst kastlar otoritesini buna bağlı olarak güçlendirir (Loomba, 2000, s. 193-194).

Benzer dönüşüm Kırsal Afrika'da ve Peru'da da yaşanır. Loomba, Kırsal Afrika'da köle ticaretinin gelişmesinin kadınların tarımsal üretim üzerindeki güçlerini kırdığını ve erkek emeğinin kentlerde yaygınlaşmasına yol açtığını söylemektedir. Bu da sonuç itibariyle kadınların erkeklere maddi olarak daha bağımlı hale gelmesine neden olur. Hıristiyanlığın yayılması, üretim ilişsilerinde ve aile yapılarında ortaya çıkan değişimler toplulukların dönüşümünde önemli bir konumdadır (Loomba, 2000, s. 193). Peru'da da benzer tahakküm, İspanyol kolonyalizmi tarafından kurulmuş ve kadınların toplumsal yaşantıya katılımı sınırlandırılmıştır. Kolonyalistler, Hıristiyan anlatılarından devraldıkları cadılık ve kirlenmişlik gibi söylemleri Güney Amerika topluluklarının kültürlerinin dönüşümünde kullanmışlar ve yapıyı bunun üzerine kurmuşlardır (Loomba, 2000, s. 195).

Görüleceği üzere Loomba, kolonyalizmin dönüştürdüğü toplumlarda kültürel geçişlere odaklandığında, karşılaştırma yöntemini zaman zaman sınıfsal çelişkilere ve üretim ilişkilerindeki dönüşümlere yaslarken; kimi zaman da kolonyalist otorite tarafindan kullanılan kültürel ve dinsel araçları öne çıkarmaktadır. Burada araçlar ve amaçlar açık hale getirildiğinde yöntemsel tutarlılık sağlanabilir. Aksi halde, tahakkümün söylemsel boyutu ve araçları, tahakkümün amaçlarından daha önemli bir görünüm kazanabilmekte; bu durum da yapılan karşılaştırmayı pragmatik ve eklektik bir düzleme taşımaktadır.

\subsection{Loomba'nın Karşılaştırmalı Yöntem İçindeki Konumu}

Loomba'nın yöntemini anlayabilmek için benzer konumdaki bir başka yazara başvurmak açıklayıcı olabilir. Chakrabarty bu anlamda önemli bir örnek olarak karşımıza çıkmaktadır. Chakrabarty (2007, s. XII), modernitenin kalkınma ve gelişmiş olanı yakalama savının aksine hiçbir ülkenin diğerine model olamayacağı tezini üretmektedir. O’na göre tarihten gelen farkl1lıklar insan topluluklarındaki temel ayrımı oluşturur. Modernitenin evrensel kavramları, daha önceden var olan kavram, sinıflandırma, kurum ve uygulamalarla kesişir ve farklılaşmalar ortaya çıkar (Chakrabarty, 2007, s. XII). Chakrabarty’nin (2007, s. 42 ve 45) yapmak istediğiyse Av- 
rupa-merkezci düşünce kategorilerini topyekûn reddetmek değil; anlatılardan, baskı ve tahakküm stratejilerinden ve modern devletin inşasından yola çıkarak tarihin/tarihlerin açıklanmasına girişmektir.

Dirlik (1998, s. 56-57), benzer konumdaki üçüncü dünya entelektüellerinin üzerinde durduğu temaları sayarken Avrupa-merkezci anlatılara yönelik eleştiriyi vurgulamaktadır. Buna göre Avrupa-merkezcilik aydınlanma sonrası Avrupa tarihinin sonucu olarak ele alınır; Şarkiyatçılık, Burjuva ideolojileri ve de Marksizm aynı eleştiriye tabi tutulur. Bu bağlamda, kolonyal geçmişe sahip toplumların üçüncü dünya olarak kodlanmasına da itiraz edilir.

Loomba'nın karşılaştırmalı yöntemine de, bu argümanların ışığında bakmak yararlı olabilir. Loomba'ya (2000, s. 277) göre evrensellik iddiasındaki Avrupa-merkezci bakıș, özellikle edebi anlatılarda belirginleșen kurgular yaratmaktadır. Bunun dıșına çıkabilmek için ele alınması gereken olgular kolonileștirilmiş toplulukların içinde yatmaktadır. Bu amaçla, "kadınların, kolonileştirilmiş halkların, Avrupalı-olmayanların anlatıları"na ve "bastırılmış öykülere ve perspektiflere" odaklanmak gerekmektedir. Bu anlamda örneğin Marksizm' in kapitalizm vurgusu tek başına işlevsel değildir; kolonyalizm karşıtı anlatılarda incelenen tarihler kapitalizmin gelişmesine yönelik açıklamaları zenginleştirmiştir (Loomba, 2000, s. 277).

Diğer yandan, Loomba'ya (2000, s. 269) göre, örneğin toplumsal cinsiyeti incelemeye katarsak tarihi sınıflar üzerinden açıklayan büyük anlatıları da yıkmış oluruz. Ancak burada ulaşılması gereken bir anlatılar çokluğu değil; hem sınıf hem toplumsal cinsiyet gibi unsurların diğer toplumsal etkenlerle nasıl buluştuğunu saptamaktır. Böylece ast grupların ve bastırılmış özelliklerin nasıl örüldüğü anlaşılabilecektir.

Loomba, anlaşılacağı üzere, yöntem itibariyle değișkenlerini kültürle sınırlamamakta; ekonomi, toplum ve politikayla ilişki kurmaya yönelmektedir (Loomba, 2000, s. 286). Bu değişkenler arasındaki dengenin ne olacağı ise yukarıda incelenen örneklerde görülmektedir. Kimi zaman toplumların kültürel dönüşümleri politik değişkenlerle ilişkilendirilmiş, kimi zaman ise ekonomik ilişkilerdeki değişiklikler kültürel araçlarla açıklanmıștır. Loomba'nın kullandığı çok tarihli ve çok parçalı yöntem bütünlüklü ve sabit bir yol izlememekte; örnekler ve olgular çerçevesinde farklılıklar içermektedir.

\subsection{Karșılaștırmalı Kamu Yönetimi, Postmodernizm ve Loomba}

Loomba'nın karşılaştırmalı kamu yönetimine yönelik olası katkılarını tartışmadan önce, karşılaştırmalı yönetimin ilgili yazınla ilișkisinin kurulması gerekmektedir. Karşılaștırmalı kamu yönetimi ortaya çıkış itibariyle modern ulus-devletlerin sınırları çerçevesinde bir inceleme alanı oluşturmuş, bürokrasi ve yönetim olgularını bu alan içerisinde incelemiştir. Ancak, küreselleşme süreci ulusal sınırların dışında bir karşılaştırmayı dayatmakta ve paralel olarak "bütün yerine parçayı yücelten felsefi postmodern yaklaşım” öne çıkmaktadır (Güler, 2013, s. 37). Güler'e (2013, s. 37) göre eşzamanlı ilerleyen küresellik ve parçalılık, bir çelişki arz etmemekte, birlikte yürümekte ve postmodernizm ya da kültürcülük gibi akımlar ulus-altı topluluklara ve yönetimlere yönelik bilgi üretmektedirler. Harvey'in $(1992$, s. 9) dikkat çektiği üzere postmodernizmin evrensel olanı reddi ve parçalılık haline eğilimi heterojen ve farklı olanın aynı zamanda özgürleştirici olduğunun veri alınmasıyla ilişkilidir. Açık ifadeyle burada parçalılık halinin tercih edildiği hususunda kuşkuya yer kalmamaktadır.

Kamu yönetimi alanında postmodernizm merkezci, ussal, evrensel ve bütünsel yapıları ve değerleri sorgulayan; bunlar yerine çoğulculuğu ve parçaların öne çıkarılmasını savunan bir konumdadır. Bu bakımdan, benzerlikler üzerine eğilmekten ziyade farklılıklar ve alt kültürler odak noktasını oluşturur (Ergun, 1997, s. 13). Güler (2013, s. 38) de buradan hareketle, ulus-altına yönelik çalışmaların, gelecekte karşılaştırmalı yönetim incelemelerinde öne çıkabileceğini iddia etmektedir. 
Loomba'nın bürokrasi ve devletlere yönelik ürettiği ayrıntılı bir bilgi bulunmamaktadır. Bu anlamda yaptığı çalışmanın postmodern kamu yönetimi yazını için yapılan tariflere birebir uyması beklenmemelidir. Öncelikle Loomba zaman ve mekân anlamında postmodern yazından da farklılaşır. Loomba, günümüz ulus-altı topluluklarına ve yönetimlerine yönelik incelemeler yapmamakta, çalışmalarını ülkeler arasında kurulan tahakküm ilişkilerinin tarihsel ve kültürel köklerini aramak üzerine kurmaktadır. Diğer yandan Loomba'nın inceleme alanı ele aldığ 1 ülkeler itibariyle, postmodern kamu yönetimi yaklaşımının teorik ve pratik yaygınlık kazandığı bir düzleme oturmamaktadır. Söyledikleri, ulus-altı ve parçacı yönetim anlayışını içermez. Ancak çalışmalarının genel olarak üzerinde durduğu konular ve kullandığı yöntem niteliksel bir tarih/tarihler incelemesi yaptığına, kültürcü bir öze sahip olduğuna ve alt kültürlere odaklandığına işaret etmektedir. Bu anlamda evrensellik iddiası taşıyan Avrupa-merkezci düşüncenin ve modernitenin dışında konumlanır. Sonuç olarak, devlet ve bürokrasiye kültürel ve tarihsel incelemelerinin 1şığında bakar.

\title{
4. Karşılaştırmalı Kamu Yönetimine Loomba'nın Sunabileceği Katkı
}

Buraya kadar anlatılanlar, Loomba'nın yöntemi ve amacı hakkında genel unsurları ortaya koymaktadır. Karşılaştırmalı kamu yönetimi açısındansa Loomba'nın, baktığı değişkenleri sıralamak yararlı olacaktır. Loomba, yerel öz kültürler, din, ırk, sınıf, toplumsal cinsiyet ve kolonyalist müdahale biçimi üzerinde durarak, kolonyalizm ve postkolonyalizm süreçlerinde yönetim ve toplum üzerine çıkarımlarda bulunmuştur. Buna göre anti-kolonyalist hareketler de ülkeden ülkeye değişiklik göstermiş ve yeni kurulan ulus-devletler de kolonyalist dönemden ve kolonyalist müdahale biçimlerinden kaynaklanan etkileri içinde barındırmış (Loomba, 2009, s. 26-30) ve bu şekilde farklılaşmıştır:

\begin{abstract}
Asya kökenli Britanyalıların kendi kendilerine tanımlama konusunda karşılaştıkları sorunlar ve baskılar, Hindistan, Pakistan ya da Bangladeş’teki halkların karşılaştıklarından farklı bir nitelik taşır. Üstelik, bu gruplar arasında bugün itibariyle ne kadar benzerlik varsa bir o kadar da farklılık var. Benzer şekilde, anti-kolonyal konumlar özgül tarihlerin damgasını taşır... Bu anti-kolonyal konumlar, aynı zamanda kolonyal egemenliğin mahiyetine göre değișiyordu. Bu yüzden, Cezayir'de Fransızlara karşı gelișen milliyetçi mücadeleler, Hindistan halkının Britanya'ya karşı direnişlerinden farklıydı; kaldı ki, bu ikisi Vietnamlıların Fransız ve Birleşik Devletler emperyalizmine karşı çıkışlarıyla da bir tutulamaz. (Loomba, 2000, s. 33)
\end{abstract}

Loomba'nın konumu bu noktada netleşmektedir. Loomba, postmodern parçalı anlatıları içeriden eleştirerek, üzerinde durduğu değişkenler arasında bağlantılar kurmaya ve ülkelerin yönetimleri ve toplumları arasındaki farklılaşmaları bu bağlamda açıklamaya çalışır. Bir başka deyişle, postmodernizme ve postkolonyalizm yazınına yine postmodern bir katkı sağlayarak ayrı ayrı parçaları birbirine bağlamak için çaba harcamaktadır:

\footnotetext{
..postkolonyalizm üzerine kaleme alınan yazıların birçoğu "melezlik”, parçalanmışlık ve çeşitlilik gibi kavramları vurgulasa da... bunun gibi terimler olsa olsa işe yarar bir kısaltma işlevi görür; çünkü farklı türden kolonyal durumları göz önünde tutmaya elverişli olmadıkları gibi, hayatları kolonyal egemenlik tarafindan yeniden yapılandırılan insanlar arasındaki sınıf, toplumsal cinsiyet, mevki, ırk, kast ya da ideoloji farklılıklarının nasıl işlediği sorununa da yer vermez. (Loomba, 2000, s. 33)
}

O halde, yönetimleri ve toplumları anlamak parçalı anlatıları birbirine bağlamaktan geçecektir. Karşılaştırma ırk, kültür, sınıf, toplumsal cinsiyet ve kolonyal tahakkümün mahiyeti gibi değişkenler üzerinden kurulacak ve mevcut yapı parçaların kendi özgül tarihleri içinde anlaşılacaktır. Toplumlar arasındaki farklılaşmalar, söz konusu değişkenlerin işleyiş̧ini kavramakla mümkündür.

Bu noktada Loomba'nın özgül tarihlerin günümüze yansımalarına yönelik verdiği birtakım örneklerden söz etmek yararlı olacaktır. Loomba'ya (2000, s. 243) göre kolonyalizm öncesi feodal dönemde Avrupa krallıkları patriyarkiye dayanan bir sisteme sahipti ve kültürel-ailevi değerler devletin kodlarına yansımaktaydı. Örneğin Kral I. James, derebeylerinin doğal babası olarak tarif edilmekteydi. Kolonyal devletler de ailevi simgelere dayanan mirası devraldı: kolonyal 
devlet tahakküm kurduğu topluluğun ebeveyni olarak kodlanmıştı. Koloni halkları, bakılması ve eğitilmesi gereken çocuklardı ve irkçı temsiller de bu ilişkilerin ürünü olarak gelişti (Loomba, 2000, s. 243).

Loomba'ya (2000, s. 153) göre medenileştirme ve terbiye misyonlarının yanında rrkçılık, kapitalizm ve devlet ilişkisinde işlevsel bir konumdaydı. Bu bağlamda, Loomba, kapitalizmin kurulması ve ırkçılık arasında bağlantıyı kolonyal devlet üzerinden kurmaktadır. Afrika örneklerinde devleti ve idari kurumları kapitalizmin yaratılmasında ideolojik işleve sahip yapılar olarak ele alarak, ırkçı ideolojileri hiyerarşik ilişkilerin meşrulaştırma aracı olarak değerlendirir. Postkolonyal dönemde ise ulus-devlet inşa süreçlerinde milliyetçi ideolojiler, devletin eğitim ve hukuk sistemleri eliyle belirginleşmektedir (Loomba, 2000, s. 224-225).

Anlatılanların 1şığında, seçkinler ve bürokrasi ilişkisini kavramak da önem kazanmaktadır. Kolonyal dönemde yabancı tahakkümün yanı sıra bürokrasinin üst kademelerine yükselen yerli seçkin gruplar, incelenmesi gereken bir başka ikiliği oluşturur; ast gruplar ve yerli seçkinler arasında yönetsel ve toplumsal anlamda keskin ayrımlar vardır (Loomba, 2000, s. 225-226). Yönetim sistemleri böyle bir yapının üstüne inşa edilmektedir.

Loomba'ya (2000, s. 267) göre, kolonyalist otorite, örneğin Güney Afrika'da koloni halkıyla ilişki kurduğunda aralarından bazılarını seçerek topluluklar içindeki mevcut hiyerarşilerin kemikleşmesini sağlamıştır ve bu durum sınıfsal ayrılıkları da netleştirmiştir. Hindistan'da Britanya kolonyalizmi, seçkinci otoriteyi yerlilerin üst sınıflarından ve erkekler arasından kurmuştur. Buna bağlı olarak otoritenin özü, kültürel ve sınıfsal kodlarıyla gelişmiş ve patriyarkal ve mülkiyetçi biçimler kazanmıştır.

Kolonyalist otoritenin biçimine göre ortaya çıkan birtakım farklılaşmalar da karşılaştırma ve yönetim açısından önemli veriler sağlayabilecek konumdadır. Örneğin, var olan toplumsal hiyerarşilerle çatışmayan ve otoritesini bu hiyerarşiler üzerine konumlandıran Britanya kolonyalizmi Bangladeş'te toplumla doğrudan ilişkiye girmezken, miras yoluyla vergi toplama hakkı kazanan yerel halktan vergi toplayıcıları uzun süre devlet adına vergi toplamayı sürdürmüştür (Loomba, 2000, s. 136). Gelgelelim, Afrika örneklerinde ırk ayrımlarının doğrudan müdahaleler üzerinde yükselmesi ve yerli nüfus içinde zenginlik açısından büyük farklılaşmaların yaşanmaması (Loomba, 2000, s. 136) da kolonyalist otoritenin nasıl kurulduğuna dair yapılacak bir karşılaştırma için önemli ipuçları vermektedir.

\section{Sonuç}

Loomba kolonyal ve postkolonyal süreçler üzerine yaptığı çalışmalarda evrensellik iddiası taşıyan Avrupa-merkezci paradigmaları eleştirmektedir. Bu bakımdan, çokkatlı ve parçalı bir incelemeye girişmektedir. Ancak aynı zamanda postmodern çalışmalara yönelttiği eleştirilerle, üzerinde durduğu katmanları ve parçaları sistematik bir biçimde bağlantılandırmaya çalışmaktadır. Bu anlamda Loomba'nın postmodern yaklaşımın boşluklarını doldurmayı amaçladığı söylenebilir. Yazarın, analizlerinde kullandığ öne çıkmaktadır.

Öte yandan, Loomba karşılaştırmalı yöntemin de Avrupa-merkezci bir içeriğe sahip olduğunu, ancak yöntemin birtakım değişikliklerle yararlı bir biçimde değerlendirilebileceğini düşünmektedir. Bu durumda Loomba, karşılaştırmalı yöntemin Avrupa'daki gelişim çizgisinin d1şında yer almakta, klasik görüşün sınırları iyi çizilmiş zaman ve mekân boyutlarının aksine esnek bir zamanlar ve mekânlar incelemesi yaratmaktadır. Buna göre incelenen alan moderniteyle ve kolonyal dönemle sınırlandırılmamalı, ülkelerin kendi özgül tarihlerini açıklayabilecek bir işlevselliğe kavuşturulmalıdır. Loomba, böylece daha geniş bir tarihsel perspektifle kolonyal tahakkümü ve postkolonyal toplumları incelemeyi amaçlamaktadır. 
Loomba için karşılaştırma, bu şekliyle, din, kültür, bilim, ırk, sınıf, ekonomi, toplumsal cinsiyet, kolonyal baskı biçimleri ve ülkelerin geleneksel-hiyerarşik toplumsal sistemleri gibi değişkenler üzerine oturur. Loomba, yöntemi bu haliyle süreçler ve mekânlar arası bir açıklayıcılığa ulaştırabileceğini düşünmektedir. Temel nokta, üçüncü dünyanın kendisine ait öyküleri yöntemdeki asli unsur kllabilmektir.

Ne var ki, Loomba'nın yöntemi birtakım sorunları da içinde barındırmaktadır. Kimi zaman görenekler ve kültürel durumlar üzerinden kurulmaya çalışılan nedensellik boşlukta kalmakta ve sonuçlar tartışmanın odağına yerleşirken, nedenler belirsiz hale gelebilmektedir. Loomba, kolonyal geçmişe sahip toplumlardaki kültürel dönüşümleri açıklarken, zaman zaman sınıfsal ve rrksal çelişsilere zaman zaman da kolonyalizmin dinsel ve kültürel müdahale biçimlerine odaklanmaktadır. Daha önce de belirtildiği gibi bu durum amaçlar ve araçlar arasındaki ayrımın bulanıklaşmasına ve neden-sonuç ilişkisinin belirsiz kalmasına yol açabilmektedir. Kısacası, Loomba, çokkatlı, çok tarihli ve parçalı bir yöntem kullanmakta ve bunu yaparken çalışmanın bütünlüğüne yönelik birtakım yöntemsel sorunlar yaşayabilmektedir.

Loomba'nın karşılaştırmalı kamu yönetimine sunabileceği katkı postmodern yaklaşıma dönük eleştirileri ve karşılaştırmalı yöntemde sahip olduğu sorunlarla birlikte düşünülmelidir. Loomba genel olarak kolonileștirilmiş halkların parçalı hikâyelerine niteliksel ve tarihsel bir analizle yaklaşır. Ele aldığı değişkenlerde başat unsur kültür olmasına rağmen, incelemesi bununla sınırlı değildir. Yönetimleri ele aldığında kültür, din, sınıf, ırk, toplumsal cinsiyet ve kolonyalist süreçlerden kalma miraslar değerlendirme kapsamına alınır. Bu yöntemsel bakımdan çoğulcu girişimiyle parçaları birbirleriyle ilişkilendirebildiği ölçüde daha açıklayıcı bir konuma yaklaşmaktadır. Örneğin ırksal ve sınıfsal kesişmeler üzerine yaptığı incelemeler, karşılaştırdığı ülkeler açısından daha derinlikli veriler sunmaktadır.

Loomba, parçalara ve alt kültürlere odaklanan postmodern anlatıları yine postmodern bir perspektiften eleştirmekte, karşılaştırmalı yöntem ve karşılaştırmalı yönetim açısından farklılıkları ve değişkenleri bağlantılandırmayı önermektedir. Bunu başarabildiği ölçüde, karşılaştırmalı yönetim incelemelerinde gelişme potansiyeli olduğu düşünülen postmodern çalışmalara yöntemsel bir katkı sunabileceği ortadadır. Aksi halde eleştirdiği yaklaşımla giderek daha çok benzeşecek, parçalara ayrılmış ve içsel olarak ilişkilendirilmemiş bir incelemeden öteye geçemeyecektir.

\section{Kaynakça}

Cohen, S. (2008). "Are we "Post"Colonial?: A Conversation with Ania Loomba". The Humanities Review. 6 (2), $121-$ 126.

Chakrabarty, D. (2007). Provincializing Europe: Postcolonial Thought and Historical Difference, New Jersey: Princeton University Press.

Dirlik, A. (1998). The Postcolonial Aura: Third World Criticism in the Age of Global Capitalism. Colorado: Westview Press.

Ergun, T. (1997). "Postmodernizm ve Kamu Yönetimi”. Amme İdaresi Dergisi. 30 (4), 3-15.

Grosfoguel, R. (2011). "Decolonizing Post-Colonial Studies and Paradigms of Political-Economy: Transmodernity, Decolonial Thinking, and Global Coloniality". Transmodernity: Journal of Peripheral Cultural Production of the LusoHispanic World. 1 (1).

Güler, B. A., (2013). “Karşılaştırmalı Kamu Yönetimi Nedir?”. Kamu Yönetimi Ülke İncelemeleri. (K. Karasu, Ed). Ankara: İmge Kitabevi. 23-39.

Harvey, D. (1992). The Condition of Postmodernity: An Enquiry into the Origins of Cultural Change, Massachusetts: Blackwell Publishers.

Hiddlestone, J. (2009). Understanding Postcolonialism. Stocksfield: Acumen.

Loomba, A. (2000). Kolonyalizm/Postkolonyalizm. (M. Küçük, Çev). İstanbul: Ayrıntı Yayınları.

Loomba, A. (2009). "Race and the Possibilities of Comparative Critique". New Literary History. 40, 501-522.

San, C. (1993). "Karşılaştırma Yönteminde Zaman ve Mekân Boyutları”. AÜSBF Dergisi. 48 (1). 155-159. 
Shankar, S. (1999). "The Origins and Ends of Postcolonial Studies”. A Review of International English Literature. 30 (4), 143-155.

University of Pennsylvania (2021). "Ania Loomba, Catherine Bryson Professor of English”. Erişim tarihi: 15.2.2021, https://www.english.upenn.edu/people/ania-loomba 